\title{
Efficiency of Photovoltaic Modules Using Different Cooling Methods: A Comparative Study
}

\section{Taiseer M. Abu-Rahmeh}

Mechanical Engineering Department, Faculty of Engineering Technology, Al-Balqa' Applied University, Amman, Jordan Email:abu_rahmeh68@yahoo.com

How to cite this paper: Abu-Rahmeh, T.M. (2017) Efficiency of Photovoltaic Modules Using Different Cooling Methods: A Comparative Study. Journal of Power and Energy Engineering, 5, 32-45.

https://doi.org/10.4236/jpee.2017.59003

Received: August 5, 2017

Accepted: September 10, 2017

Published: September 13, 2017

Copyright @ 2017 by authors and Scientific Research Publishing Inc. This work is licensed under the Creative Commons Attribution International License (CC BY 4.0).

http://creativecommons.org/licenses/by/4.0/

\begin{abstract}
This paper presents an experimental investigation of the efficiency of a photovoltaic module using different cooling methods. The performance of the PV panels under different cooling techniques for the same operational conditions is explained. A special test rig was designed and installed in the Faculty of Engineering Technology, East Amman. All operating key variables such as solar radiation intensity, ambient and module temperatures using calibrated devices were measured and recorded as well as the electrical output. The present experiments results showed that the electrical efficiency of the tested PV panels is improved significantly when it was cooled. However, the best improvement obtained when a nanofluid $\left(0.04 \% \mathrm{wt} \mathrm{TiO}_{2} /\right.$ water $)$ is used as a cooling medium, while the PV panel cooled by using Aluminum rectangular fins showed the lowest efficiency improvement. Such results including the comparative analysis (under local operating conditions prevailing in Jordan) are in agreement with literature and could be useful for researchers and developers of solar power generation.
\end{abstract}

\section{Keywords}

Cooling, Photovoltaic, Nanofluid, Fins, PV Efficiency

\section{Introduction}

Based on forecasts by researchers and concerned international agencies, the proven reserves of fossil fuels, e.g. oil and gas, at the current rate of world's consumption, will not be adequate to meet future demand for more than the coming five decades. What is equally important is the growing concern about environmental pollution that caused by burning conventional fuels. Thus, it is expected 
that the contribution of available renewable energy sources will increase significantly in the future to meet the growing energy demand world-wide. This is a true fact expressed by statistics published recently by specialized energy agencies such as IRENA and IEA. According to the International Renewable Energy Agency (IRENA), renewable electricity generation in 2015 was 191 TWh. This amount was higher than the prevailed rate in 2014 by about 3.5\% [1]. Although solar energy is not consistent and has low intensity, the global installed capacity for solar-powered electricity has seen an exponential growth, reached around 227 GWe at the end of 2015, producing $1 \%$ of all consumed electricity in the world. The total capacity for solar heating and cooling in operation in 2015 was estimated at 406 GWth [2].

Locally, the Government of Jordan, GoJ, has taken necessary steps to promote renewable energy (RE) projects and enhance $\mathrm{EE}$ in all sectors of the economy. In order to attract the private sector participation in the development of RE, a new system of Direct Proposals has been approved and issued, this resulted in the awarding of about 1335 MWe of RE capacities in the 1st and 2nd rounds of direct proposals. Of which more than $400 \mathrm{MW}$ are operational at the end of 2016, in addition to about $80 \mathrm{MW}$ of small PV systems as roof tops [3]. The 3rd round, with a total capacity of 300 (200 PV and 100 Wind) MW, and the proposals, based on BOO basis for a $50 \mathrm{MW}$ block in, by the qualified companies or investors are under evaluation. The GoJ, represented by the Ministry of Energy and Mineral Resources and Energy and Minerals commission, also has issued a well-developed and comprehensive technical codes and regulations for on-grid RE projects. This will lead to higher dependence on RE systems, in particular PV generation systems due to low cost of produced electricity from such systems compared with other alternatives [4]. The recent signed power purchase agreement with the GoJ to supply the national grid with generated electricity from a central PV system, connected to high voltage grid, achieved a very competitive price of about 0.05 USD per kWh delivered compared with about 0.16 USD per $\mathrm{kWh}$ for PV projects signed in 2014 [5]. Such low cost was also reported in other projects elsewhere [6], which are much cheaper than other conventional power generation systems. This is as a result of accelerated improvement due to intensive research and development in this field as well as increased mass production of PV modules world-wide which led to further reduction in prices of solar PV modules [2].

In addition to lower costs of PV modules and consequently generated power, the environmental dimension of solar energy is becoming an important advantage for such systems. Solar PV is clean and involves no direct-pollution. Therefore, it is believed widely that solar energy, and PV in particular, should be utilized instead of other existing conventional energy forms, even with slightly higher costs to generate electrical power. Solar energy has a wide spectrum of applications such as solar thermal utilization, photovoltaic power generation. However, photovoltaic technology $(\mathrm{PV})$ is one of the most important promising renewable 
energy technologies [7] [8] [9]. However, photovoltaic final efficiency is still considered as one of most significant drives for development and industrial manufacturing of such conversion systems. Thus, developers and researches prime aim is to lower the cost, increase the efficiency, and develop new technologies related to PV cells, materials and solar tracking [10].

One of the effective methods of improving efficiency of a photovoltaic (PV) module is by decreasing its operating surface temperature. A typical value for PV efficiency loss with increasing temperature is $0.5 \%{ }^{\circ} \mathrm{C}$ [11]. Lowering surface temperature can be achieved by cooling the PV module during operation which leads to higher heat dissipation rates from PV modules [12] [13] [14] [15]. As a result, most of the up to date research has tended to apply different methods to cool PV cells [16]-[22]. Therefore, adding an artificial cooling system to reduce the PV module surface temperature and increase its power output and efficiency is under investigation.

In this research paper, different cooling methods have been conducted: 1) using rectangular fins; 2) tap-water and/or; 3) nanofluids. Fins cooling of PV modules was studied by different researchers. Bryce et al. [23] have investigated cooling of a PV panel via fins and a duct attached to the rear surface of the panel. It was found that electrical output varies weakly with fin material and thickness, but strongly with fin length and air velocity in the duct. The impacted of tilted heat sinks was studied by Mittelman et al. [24] and Do et al. [25]. The latter proposed a correlation between the fin geometries, the tilt angles and the heat transfer coefficients. Other researchers used spray-water, on the back surface, to cool down PV modules in order to improve its efficiency [26] [27] [28]. It has been concluded that such system based on evaporative cooling could reduce modules' temperature by $10^{\circ} \mathrm{C}$ when operated for 5 minutes. Although nanofluids was introduced by Chao in 1995, the use of such newly fluids still receiving high attention by researchers for different applications, including energy systems [29]. Recently nanofluids were used by different researchers to cool different thermal systems, including PVs [30]-[40]. The main conclusion was that an augmentation of particle concentration has produced a clear decrease of the junction temperature between the heated component and the cooling block. This is due to high thermal conductivity of solids with very small size in the order of few micrometers. For more details, readers could visit the following research [41].

In open literature, there are voluminous research works of theoretical and experimental studies for hybrid photovoltaic thermal systems [42] [43] [44] [45] [46]. For example, Agrawal and Tiwari [47] evaluated the performance of hybrid micro channel photovoltaic thermal system (MCPVT) used to produce electrical power and hot water simultaneously. Also Ibrahiem et al. [46] analyzed the performance of such system under conditions prevailed in Malaysia. From previous research papers, it was evident that key questions still linger concerning the best nanoparticle-and-liquid pairing and conditioning, reliable measurements of achiev- 
able thermal conductivity of employed nanofluid and sound simulation models that fully describe the particle dynamics and heat transfer of such nanofluids [48]. Mahian et al. [49] in their review paper they investigated nanofluids' applications in solar thermal engineering systems with the prime aim of enhancing efficiency and performance of such systems. Others [50] [51] [52] concentrated their efforts on the use of nanofluids in direct solar collectors for solar-thermal energy conversion. They reported that size reduction and cost savings are inevitable when nanofluids are used. Karami and Rahimi [53] [54] and Mittal et al. [55] studied possibilities of enhancing heat transfer in PV modules using different nanofluids. It was concluded that the average PV surface temperature could be decreased significantly by using nanofluids.

In a previous paper by Al-Busoul et al. [56], the performance of a cooled PV module by using $\mathrm{Al}_{2} \mathrm{O}_{3}$ and $\mathrm{TiO}_{2}$ nanofluids with different concentrations was studied under local conditions. It has been found that there is a significant increase in both of output power and final efficiency of all tested modules when nanofluids employed to cool down the PV module. The highest possible enhancement, under the local testing conditions, was observed for a nanofluid based on $\mathrm{Al}_{2} \mathrm{O}_{3}$ with a concentration of $0.02 \%$ by wt. In this new experimental investigation and despite numerous works done in this field, the main objective of the present work is to determine the most appropriate cooling method that may be employed to improve the performance, output power and efficiency of the PV module under local operating conditions prevailing in Jordan. It is important to stress here that there is still a gap in available information related to comparison between different cooling methods of PV modules. Such missing info could be useful and help all stakeholders to understand the effect of increasing the temperature of PV module which drastically decrease its efficiency and consequently the generated power. Bearing in mind that at present in the Middle East and North Africa (MENA) region, which enjoys high solar radiation and relatively high atmospheric temperature as well as dry climate, there is a growing trend to install PV modules in both distributed and central systems.

\section{Experimental Apparatus and Procedure}

In this research work a tailor-made test rig was fabricated and assembled based on available resources and materials in the local market. The experimental system is shown in Figure 1. As can be seen from this figure, there are four PV modules 1) that are connected in parallel and all of these modules are working under same operating conditions (i.e. solar irradiation intensity, atmospheric temperature, wind speed, and dust content in the atmosphere). The first and second PV modules are cooled using water and a nanofluid, respectively, flowing inside copper tubes with the diameter of $6 \mathrm{~mm}$ attached to the back surface of the module, with a total length of 3 meters.

The third PV module is cooled by using 24 vertical Aluminum rectangular fins (length $=395 \mathrm{~mm}$, height $=20 \mathrm{~mm}$, thickness $=2 \mathrm{~mm}$ ) attached to the back 


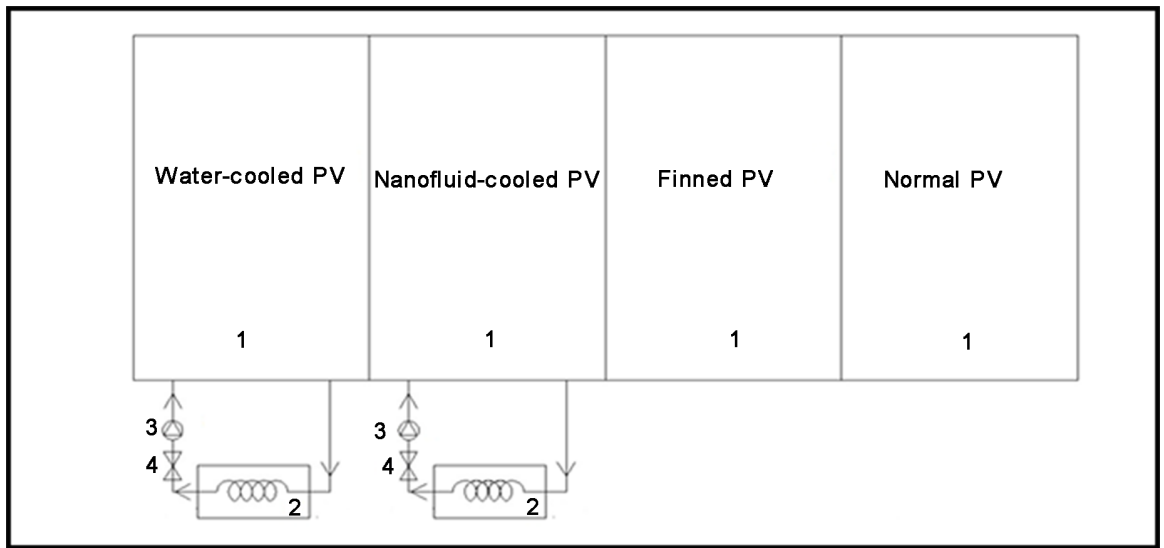

Figure 1. Cooling system for PV module. 1) PV module; 2) Coolant heat exchanger; 3) Pump and; 4) Throttling valve.

surface of the module. The back surface of the first, second and third modules are shown in Figure 2, while the fourth PV module is left without any cooling, i.e. plain with natural cooling. A special tube-heat exchanger 2) was designed to reject heat to the sink, which is a large tank filled with cold water. This tube coil is made of $6 \mathrm{~mm}$ copper tube, with a total length of about 2 meters, and connected to a small circulating pump 3) that used to drive the cooling fluid through heat exchangers. A throttling valve 4) was used to control the flow rate in the circuit.

\section{Preparation of Nanofluid}

In this study a nanofluid (metal oxide) with water as base fluid was used. $\mathrm{TiO}_{2}$ nanoparticles with an average grain size of about (30 - 50) nm were utilized. This was grinded and separated in a specialized laboratory, i.e. Royal Scientific Society (RSS), in Jordan. The used nanofluid also was made by an expert in RSS laboratory with the desired specs. In order to prepare the nanofluid, deionized water (the basis of the nanofluid) was mixed with the required mass grinded solid material, i.e. nanoparticles, to attain the required concentration (i.e. $0.04 \%$ by weight). Then, the nanoparticles were dispersed in the deionized water and the solution was sonicated by an ultrasonic device for a minimum time of 90 minutes in order to obtain a uniformly dispersed solution. The obtained properties of the yielded nanofluid are summarized in Table 1.

The thermal conductivity of nanofluid $k_{\text {eff }}$ was calculated using the following equation [13]:

$$
k_{\text {eff }}=k_{f}+3 \psi^{-1} v_{p} \frac{k_{p}-k_{f}}{\left(3 \psi^{-1}-1\right) k_{f}+k_{p}-v_{p}\left(k_{p}-k_{f}\right)} k_{f}
$$

where:

$k_{\text {effi }}$ Thermal conductivity of nanofluid,

$k_{\dot{*}}$ Thermal conductivity of based fluid,

$k_{p}$ : Thermal conductivity of particles, 


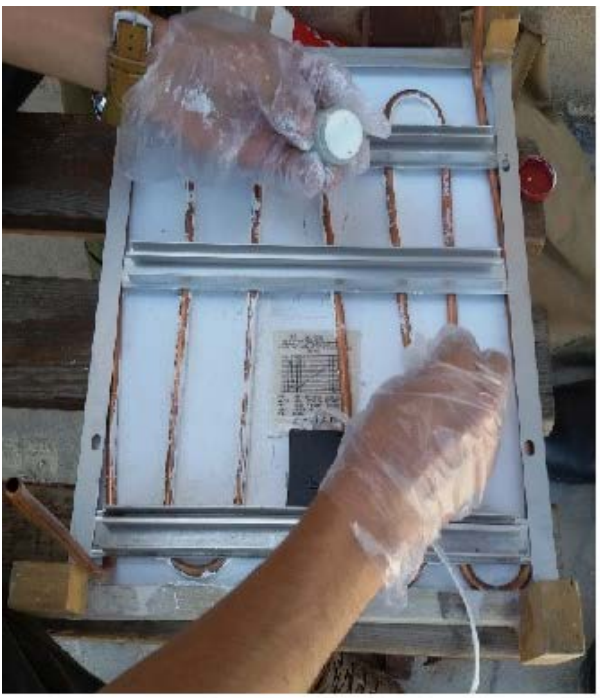

(a)

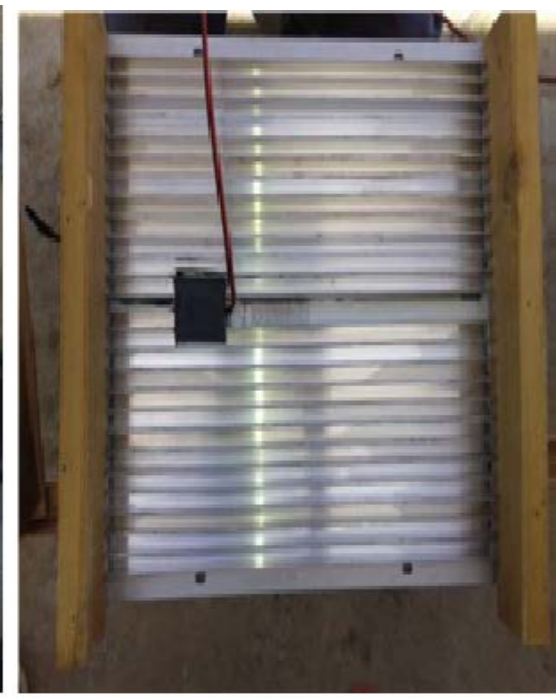

(b)

Figure 2. (a) Back surface of PV module cooled by water and nanofluids; (b) Back surface of PV module cooled by rectangular fins.

Table 1. Physical properties of $0.04 \%$ by weight $\mathrm{TiO}_{2}$ nanofluid.

\begin{tabular}{ccccccccc}
\hline$M_{\mathrm{TiO}_{2}}$ & $V_{\text {water }}$ & $\rho_{\text {water }}$ & $\rho_{\mathrm{TiO}_{2}}$ & $\rho_{\mathrm{NF}}$ & $k_{\text {water }}$ & $k_{\mathrm{TiO}_{2}}$ & $k_{\text {eff }}$ & By weight \\
\hline $\mathrm{kg}$ & $\mathrm{Lit}$ & $\mathrm{kg} / \mathrm{m}^{3}$ & $\mathrm{~kg} / \mathrm{m}^{3}$ & $\mathrm{~kg} / \mathrm{m}^{3}$ & $\mathrm{~W} / \mathrm{m} . \mathrm{K}$ & $\mathrm{W} / \mathrm{m} . \mathrm{K}$ & $\mathrm{W} / \mathrm{m} . \mathrm{K}$ & $\%$ \\
0.004 & 10 & 999 & 4230 & 1029.7 & 0.613 & 11.8 & 0.628 & 0.04 \\
\hline
\end{tabular}

$v_{p}:$ Volume fraction of nanoparticles,

$\psi$. Sphericity of the particles ( $\psi=1$ for spherical and 0.5 for cylindrical).

It is necessary to mention that the volume flow rate of water and nanofluid in this work remained unchanged $(0.1313 \mathrm{~L} / \mathrm{s})$ in all experiments in order to be able to evaluate effects of other key parameters. The performance of the modules was monitored through the measurement of 1) PV back surface temperature by using type T-thermocouple; 2$)$ solar radiation intensity $\left(\mathrm{W} / \mathrm{m}^{2}\right)$ by using a calibrated solar power meter; and 3) the yielded output power by using AVO meter to measure open circuit voltage and short circuit current. Measurement devices with their main specification are shown in Figure 3.

In all experiments, measuring devices were reset and tested before conducting any measurement to ensure validity of all readings. The experimental rig was run by same group in order to minimize differences and personal error. The test procedure was started by cleaning PV modules, checking all connections and examining the tilt angle and direction facing the south. Then recording measured variables for short intervals of 5 minutes for all modules. It is important to mention here that experiments were repeated three times in order to make sure that the effect of other factors such as dis-uniformity and externalities has no influence on obtained results. Same procedure was followed in all experiments to reduce uncertainty and have sound representative results. 


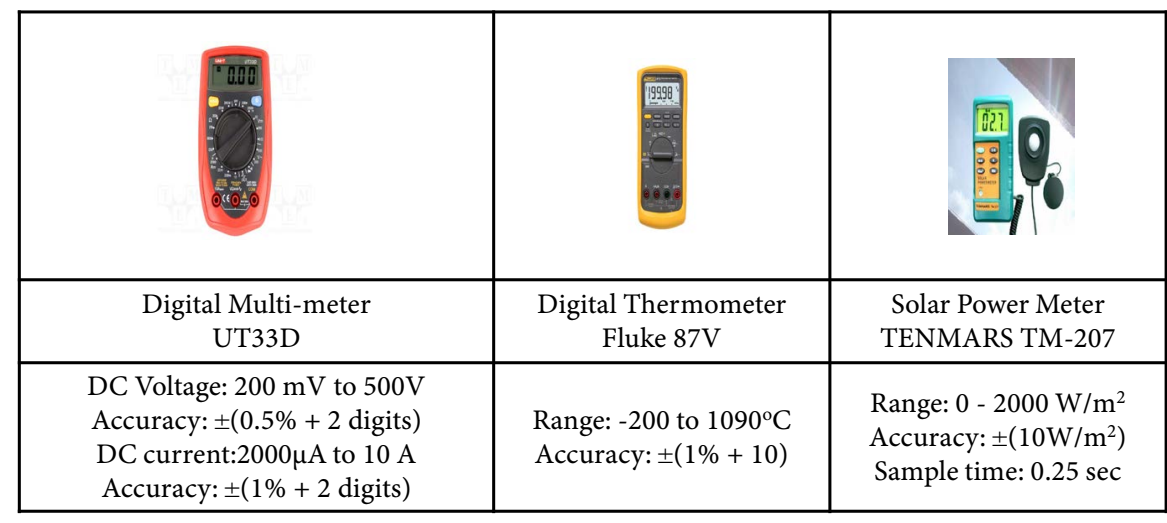

Figure 3. Measuring devices used to monitor the performance of PV modules.

\section{Results and Discussion}

The effect of different cooling methods (free-cooling by using fins, water and nanofluid of $0.04 \%$ wt $\mathrm{TIO}_{2} /$ water) on efficiencies of silicon PV modules was analyzed. The effectiveness of cooling of different cooling methods was evaluated and compared with obtained results for normal free-cooling PV module under same operating conditions. The fact that solar irradiation varies on daily basis was considered by taking an average for a testing period of five days. The standard performance, e.g. output and efficiency, of a PV module was calculated and analyzed by employing specialized commercial software, i.e. $\mathrm{PV}_{\mathrm{SYS}} 6.0$, which is available freely on the web [57]. It is worth to be mentioned that all data presented in the following figures are an average of the results of five continuous days ( $1^{\text {st }}$ to $5^{\text {th }}$ of July, 2015).

Figure 4 shows the average solar radiation intensity during the experiment period and as can be seen from this figure that solar irradiation varies daily with peak recorded at solar noon. The max measured value was $846 \mathrm{~W} / \mathrm{m}^{2}$, which is in good agreement with published data of nearest weather station based in Amman Airport [58].

The measured hourly surface temperature of four PV modules and ambient temperature are shown in Figure 5. It can be noticed that the surface temperature of the PV modules has reached its maximum at 12:00 noon and the maximum temperature difference between back surface of PV module and dry air temperature $\left(\mathrm{T}_{\mathrm{s}}-\mathrm{T}_{\text {ambient }}\right)$ was about $19.2^{\circ} \mathrm{C}$ for the normal cooled PV module and occurred between 11:00 am and 12:00, while the maximum temperature difference recorded for the module cooled with $\mathrm{TiO}_{2}$ nanofluid was about $8.1^{\circ} \mathrm{C}$ at same time. For the other two modules, water and fins-cooled, it was observed that such difference was $9.5^{\circ} \mathrm{C}$ and $12.19^{\circ} \mathrm{C}$, respectively. It is clear that the nanofluid-cooled module has the lowest temperature difference which means that an effective cooling has achieved. It is clearly shown in Figure 5 that such temperature difference, in the case of using nanofluid, is much less in the morning (about $4^{\circ} \mathrm{C}$ ) and in late afternoon dropped further $\left(-6^{\circ} \mathrm{C}\right)$. This could be attributed to different factors, but the most important being the lower ambient 


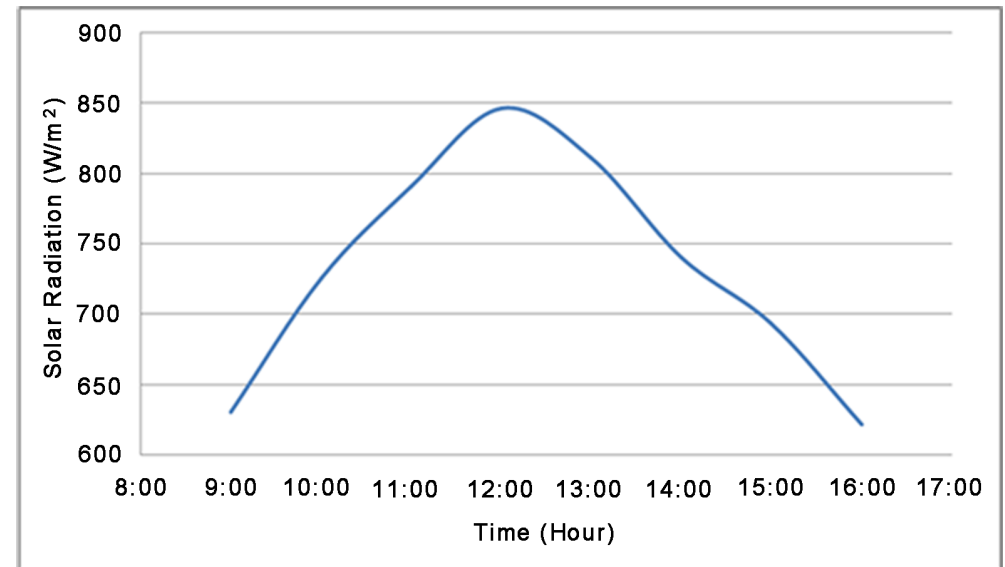

Figure 4. Solar radiation intensity during July 2015.

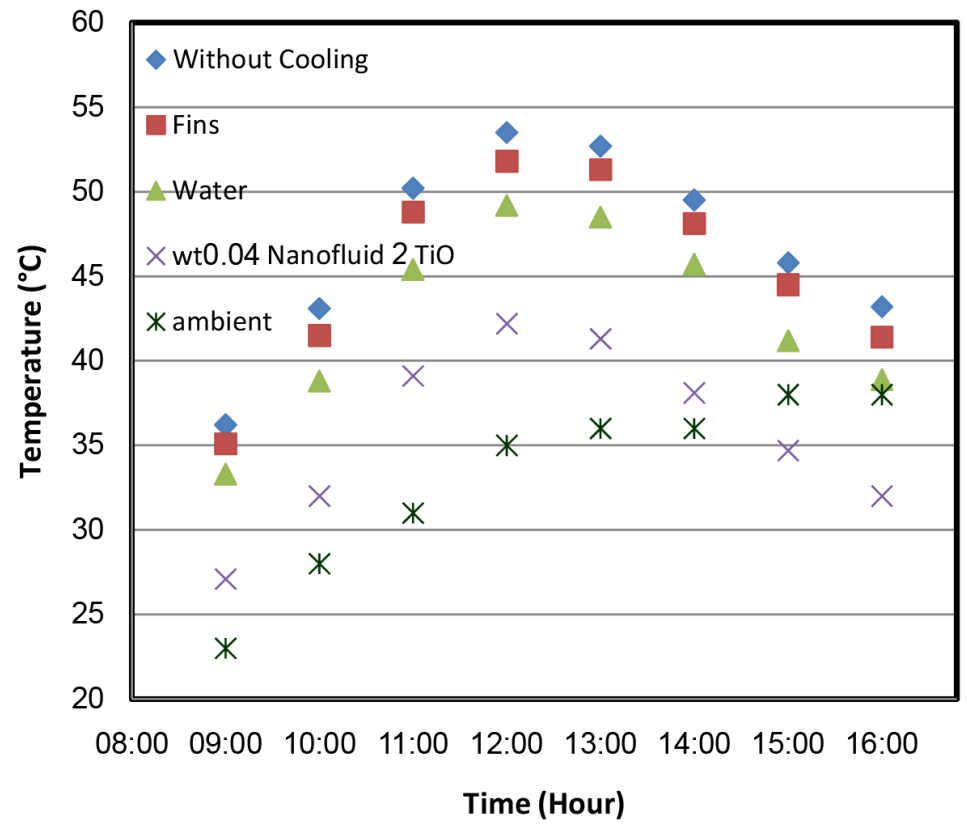

Figure 5. Average surface module temperature during the experiment $\left(1^{\text {st }}\right.$ to $5^{\text {th }}$ of July, 2015).

temperature in early morning and late evening, reduced incoming solar radiation and the fact that the back surface temperature of tested PV module was lower than the ambient temperature as a result of continuous cooling without altering the flow rate.

The hourly electrical output power is given in Figure 6. The values of the electrical power varied slightly following changes in solar radiation intensity and PV surface temperature. It has been found that this output was the max for the PV cooled by $\mathrm{TiO}_{2}$ nanofluid, since it has the lowest surface temperature and the maximum yielded electricity values at 12:00 noon were $(15.7,15.3,15.1$ and 14.9 W) for $0.04 \%$ wt- $\mathrm{TiO}_{2}$, water, fins cooled PV modules and normal PV module, respectively. 


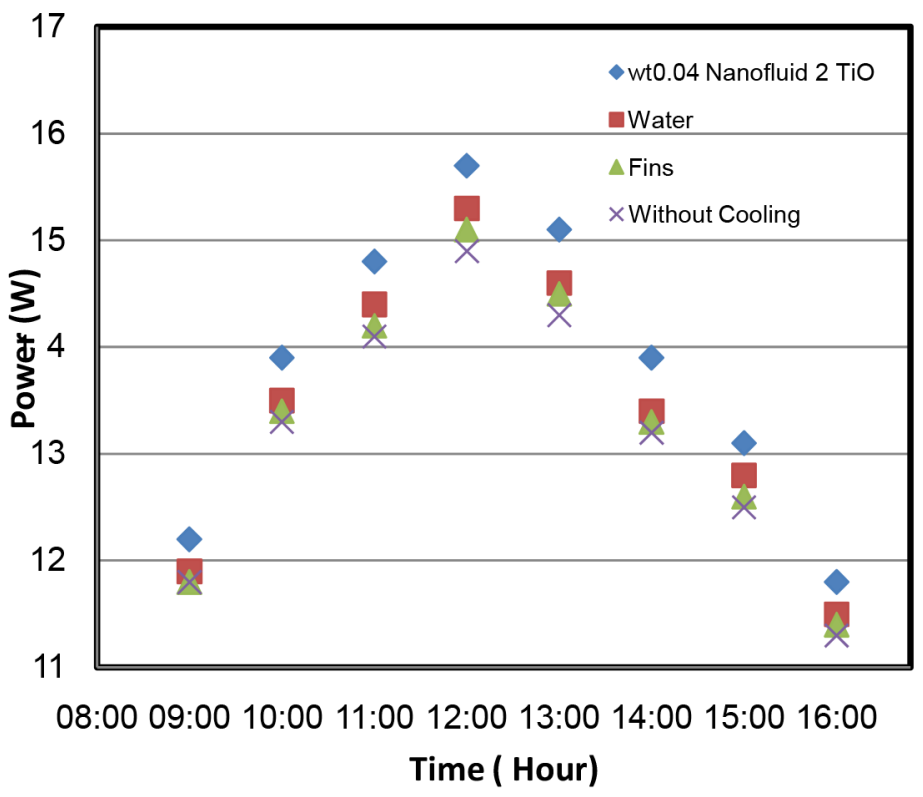

Figure 6. Hourly output electrical power of the tested PV modules.

The final efficiency of the tested PV modules is illustrated in Figure 7. Efficiency varied during the test period due to changes in solar radiation intensity and PV surface temperature. But it is witnessed that all cooling methods follow same pattern: high efficiency in early morning and late afternoon, while the lowest efficiency occurred during mid of the day. Moreover, it has been observed that $\mathrm{PV}$ efficiency for cooled module by $\mathrm{TiO}_{2}$ nanofluid is higher than the other modules $\left(13.39 \%, 12.99 \%, 12.88 \%\right.$ and $12.71 \%$ for $0.04 \%$ wt- $\mathrm{TiO}_{2}$ nanoflids, water, fins cooled and normal PV module, respectively). The explanation for such behavior is that the obtained efficiency is inversely related with surface temperature, while the power output is directly proportional to solar radiation intensity. Bearing in mind that the output power is also proportional to the module short circuit current, which slightly increases with temperature, while inversely proportional to the module open circuit voltage. It is important to mention here that results of this research work are in good agreement with those reported in previous similar work by other researchers [49]-[54].

The hourly relative efficiency (ratio between cooled and normal PV modules) is shown in Figure 8. The maximum improvement in energy conversion was about $6.5 \%$ when using nanofluid, while this was much lower for other cooling methods, i.e. $2.7 \%$ and $1.46 \%$ for water and fins, respectively.

To sum up, the obtained results in this research work proved that PV module efficiency could be improved when applying cooling on the back surface of the module. Higher efficiency could be achieved when nanofluid was used to cool down the PV module. In the future a research work to investigate the possibility of integrating water desalination and power generation using PV modules for residential applications will be conducted to examine the feasibility of such system. 


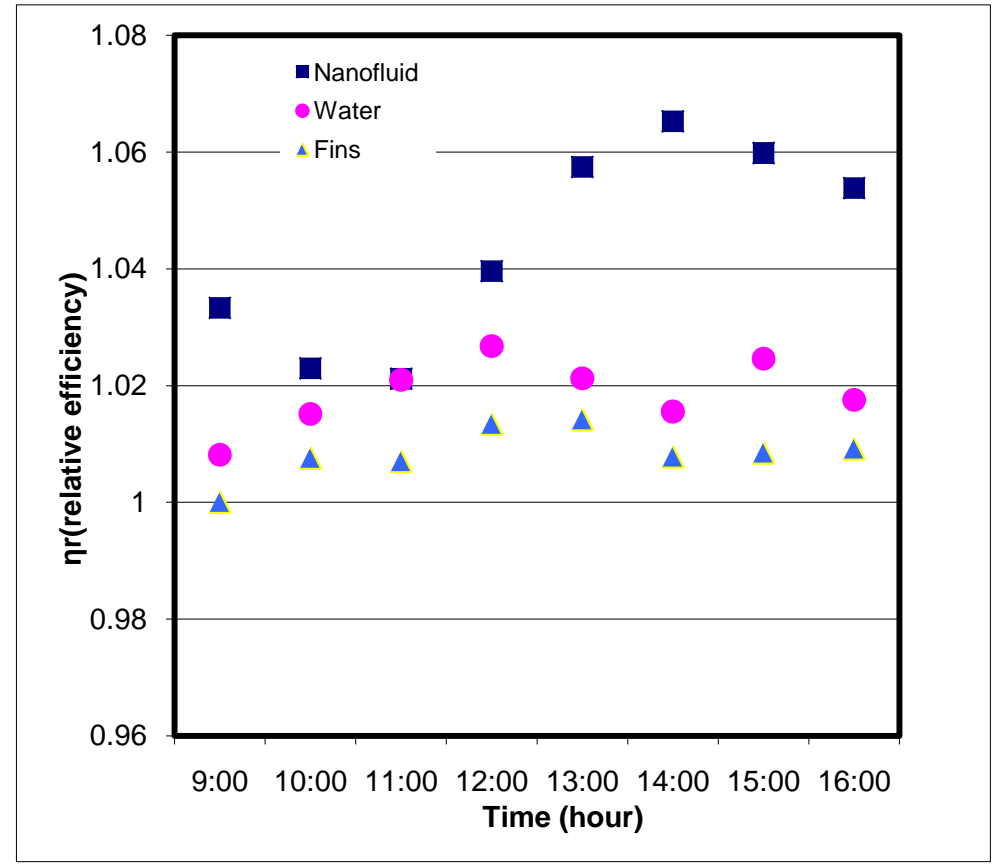

Figure 7. Hourly electrical efficiency of the tested PV modules.

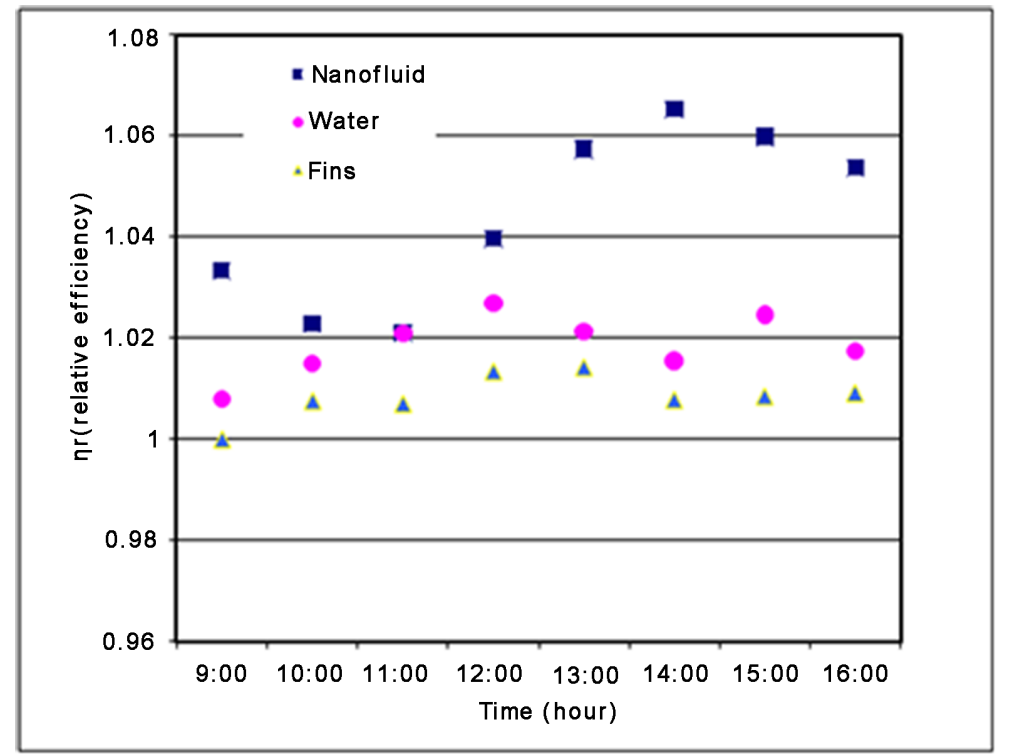

Figure 8. Hourly relative efficiency (ratio between cooled and uncooled) of tested PV modules.

\section{Conclusion}

This experimental study aimed to assess the performance of PV modules when applying different cooling methods: nanofluid, tap water and fins. The obtained results are compared with a standard uncooled PV module. The measured key variables, under same operating conditions, were reported and analyzed and compared with the base case-scenario. The obtained results clearly demonstrate that cooling the PV module enhanced heat transfer and thus achieving higher 
electrical efficiency. The main conclusion of the paper in hand is that the electricity yield of the $\mathrm{PV}$ module cooled by $0.04 \% \mathrm{wt} \mathrm{TiO}_{2}$, water and fins compared with uncooled PV was higher by $5.37 \%, 2.62 \%$ and $1.34 \%$, respectively. As expected in all cases, same pattern noticed following solar radiation intensity and ambient temperature. Based on the obtained results, it is strongly believed that PV cooling is most effective during mid-day period. Future research work will address the integration of PV based power generation and water desalination. This is extremely important for a country like Jordan, which ranked as $2^{\text {nd }}$ in the world in terms of water resources poverty.

\section{References}

[1] International Renewable Energy Agency (2017) Renewable Energy Highlights.

[2] World Energy Council (2016) World Energy Resources, 2016 Summary.

[3] Annual Report 2016 (2017) Energy and Minerals Commission. Amman.

[4] Annual Report 2016 (2017) Ministry of Energy and Mineral Resources. Amman.

[5] Annual Report 2016 (2017) National Electric Power Company. Amman.

[6] International Renewable Energy Agency (2017) REN21 Global Status Report 2017.

[7] Yang, L., Xuan, Y., Han, Y. and Tan, J. (2012) Investigation on the Performance Enhancement of Silicon Solar Modules WITH an Assembly Grating Structure. Energy Conversion Management, 54, 30-37. https://doi.org/10.1016/j.enconman.2011.09.017

[8] Mc Govern, R.K. and Smith, W. (2012) Optimal Concentrations and Temperatures of Solar Thermal Power Plants. Energy Conversion Management, 60, 226-232. https://doi.org/10.1016/j.enconman.2011.11.032

[9] Meral Mehmet, E. and Dincer, F. (2011) A Review of the Factors Affecting Operation and Efficiency of Photovoltaic Based Electricity Generation System. Renewable sustainable Energy, 15, 2176-2184. https://doi.org/10.1016/j.rser.2011.01.010

[10] Fernández, A. and Dieste, J.A. (2013) Low and Medium Temperature Solar Thermal Collector Based in Innovative Materials and Improved Heat Exchange Performance. Energy Conversion and Management, 75, 118-129. https://doi.org/10.1016/j.enconman.2013.06.007

[11] Sahay, A., Sethi, V.K., Tiwari, A.C. and Pandey, M. (2015) A Review of Solar Photovoltaic Panel Cooling Systems with Special Reference to Ground Coupled Central Panel Cooling System (GC-CPCS). Renewable and Sustainable Energy Reviews, 42, 306-312.

[12] Skoplaki, E. and Palyvos, J.A. (2009) On the Temperature Dependence of Photovoltaic Module Electrical Performance: A Review of Efficiency/Power Correlations. Solar Energy, 83, 614-624.

[13] Radziemska, E. and Klugmann, E. (2002) Thermally Affected Parameters of the Current-Voltage Characteristics of Silicon Photocell. Energy Conversion and Management, 43, 1889-1900.

[14] Han, X., Wang, Y. and Zhu, L. (2013) The Performance and Long-Term Stability of Silicon Concentrator Solar Cells Immersed in Dielectric Liquids. Energy Conversion and Management, 66, 189-198.

[15] Böer, K.W. (2013) Cadmium Sulfide Enhances Solar Cell Efficiency. Energy Conversion and Management, 52, 426-430. 
[16] Barrau, J., Rosell, J., Chemisana, D., Tadrist, L. and Ibañez, M. (2011) Effect of a Hybrid Jet Impingement/Micro-Channel Cooling Device on the Performance of Densely Packed PV Cells under High Concentration. Solar Energy, 85, 2655-2665.

[17] Teo, H.G., Lee, P.S. and Hawlader, M.N.A. (2012) An Active Cooling System for Photovoltaic Modules. Applied Energy, 90, 309-315.

[18] Do, K.H., Kim, T.H., Han, Y.-S., Choi, B.-I. and Kim, M.-B. (2012) General Correlation of a Natural Convective Heat Sink with Plate-Fins for High Concentrating Photovoltaic Module Cooling. Solar Energy, 86, 2725-2734.

[19] He, W., Chow, T.-T., Ji, J., Lu, J., Pei, G. and Chan, L.-S. (2006) Hybrid Photovoltaic and Thermal Solar-Collector Designed for Natural Circulation of Water. Applied Energy, 83, 199-210.

[20] Hegazy, A.A. (2000) Comparative Study of the Performances of Four Photovoltaic/Thermal Solar Air Collectors. Energy Conversion and Management, 41, 861-881.

[21] Othman, M.Y.H., Yatim, B., Sopian, K. and Abu Bakar, M.N. (2005) Performance Analysis of a Double-Pass Photovoltaic/Thermal (PV/T) Solar Collector with CPC and Fins. Renewable Energy, 30, 2005-2017.

[22] Moharram, K.A., Abd-Elhady, M.S., Kandil, H.A. and El-Sherif, H. (2013) Enhancing the Performance of Photovoltaic Panels by Water Cooling. Ain Shams Engineering Journal, 4, 869-877.

[23] Bryce, C., King, J. and Tingleff (2006) Cooling of Photovoltaic Cells. http://bob.tingleff.com/pvcooling.pdf

[24] Mittelman, G., Dayan, A., Dado-Turjeman, K. and Ullmann, A. (2007) Laminar Free Convection underneath a Downward Facing Inclined Hot Fin Array. International Journal of Heat and Mass Transfer, 50, 2582-2589.

[25] Do, K.H., Kim, T.H., Han, Y.-S., Choi, B.-I. and Kim, M.-B. (2012) General Correlation of a Natural Convective Heat Sink with Plate-Fins for High Concentrating Photovoltaic Module Cooling. Solar Energy, 86, 2725-2734.

[26] He, W., Chow, T.-T., Ji, J., Lu, J., Pei, G. and Chan, L.-S. (2006) Hybrid Photovoltaic and Thermal Solar-Collector Designed for Natural Circulation of Water. Applied Energy, 83, 199-210.

[27] Moharram, K.A., Abd-Elhady, M.S., Kandil, H.A. and El-Sherif, H. (2013) Enhancing the Performance of Photovoltaic Panels by Water Cooling. Ain Shams Engineering Journal, 4, 869-877.

[28] Alami, A.H. (2014) Effects of Evaporative Cooling on Efficiency of Photovoltaic Modules. Energy Conversion and Management, 77, 668-679.

[29] Choi, U.S. (1995) Enhancing Thermal Conductivity of Fluids with Nanoparticles. Fluids Engineering Division, 231, 99-103.

[30] Nguyen, G.R.C.T., Gauthier, C. and Galanis, N. (2007) Heat Transfer Enhancement using $\mathrm{Al}_{2} \mathrm{O}_{3}$-Water Nanofluid for an Electronic Liquid Cooling System. Applied Thermal Engineering, 27, 1501-1506.

[31] Elmir, R.M.M. and Mojtabi, A. (2012) A Vertical Magneto-Convection in Square Cavity Containing Al2O3/Water Nanofluid: Cooling of Electronic Compounds. Energy Procedia, 18, 724-732.

[32] Ijam, R.S.A. (2012) Nanofluid as a Coolant for Electronic Devices (Cooling of Electronic Devices). Applied Thermal Engineering, 32, 76-82.

[33] Hung, W.Y.T. (2012) Enhancement of Thermal Performance in Double-Layered Microchannel Heat Sink with Nanofluids. International Journal of Heat and Mass 
Transfer, 55, 3225-3238.

[34] Peyghambarzadeh, S.H.H.S.M., Seifi Jamnani, M. and Hoseini, S.M. (2011) Improving the Cooling Performance of Automobile Radiator with $\mathrm{Al}_{2} \mathrm{O}_{3}$ /Water Nanofluid. Applied Thermal Engineering, 31, 1833-1838.

[35] Wang, X.-D., Bin, A. and Xu, J.-L. (2013) Optimal Geometric Structure for Nanofluid-Cooled Microchannel Heat Sink under Various Constraint Conditions. Energy Conversion and Management, 65, 528-538.

[36] Ting, T.W., Hung, Y.M. and Guo, N. (2014) Effects of Streamwise Conduction on Thermal Performance of Nanofluid Flow in Microchannel Heat Sinks. Energy Conversion and Management, 78, 14-23.

[37] Hatami, M. and Ganji, D.D. (2014) Thermal and Flow Analysis of Microchannel Heat Sink (MCHS) Cooled by Cu-Water Nanofluid using Porous Media Approach and Least Square Method. Energy Conversion and Management, 78, 347-358.

[38] Ghazvini, M. and Shokouhmand, H. (2009) Investigation of a Nanofluid-Cooled Microchannel Heat Sink using Fin and Porous Media Approaches. Energy Conversion and Management, 50, 2373-2380.

[39] Xu, Z. and Kleinstreuer, C. (2014) Concentration Photovoltaic-Thermal Energy Co-Generation System using Nanofluid for Cooling and Heating. Energy Conversion and Management, 87, 504-512.

[40] Bozorgan, N. and Shafahi, M. (2015) Performance Eveluation of Nanofluid in Solar Energy: A Review of the Recent Literature. Micro and Nano Systems Letters, 3, $2-15$.

[41] Das, S.K., Choi, S.U.S. and Patel, H.E. (2006) Heat Transfer in Nanofluids-A Review. Heat Transfer Engineering, 27, 3-19. https://doi.org/10.1080/01457630600904593

[42] Sarhaddi, F., Farahat, S., Ajam, H., Behzadmehr, A. and Mahdavi Adeli, M. (2010) An Improved Thermal and Electrical Model for a Solar Photovoltaic Thermal (PV/T) Air Collector. Applied Energy, 87, 2328-2339.

[43] Agrawal, S. and Tiwari, G.N. (2011) Energy and Exergy Analysis of Hybrid Micro-Channel Photovoltaic Thermal Module. Solar Energy, 85, 356-370.

[44] Rajoria, C.S., Agrawal, S. and Tiwari, G.N. (2012) Overall Thermal Energy and Exergy Analysis of Hybrid Photovoltaic Thermal Array. Solar Energy, 86, 1531-1538.

[45] Kribus, A., Kaftori, D., Mittelman, G., Hirshfeld, A., Flitsanov, Y. and Dayan, A. (2006) A Miniature Concentrating Photovoltaic and Thermal System. Energy Conversion and Management, 47, 3582-3590.

[46] Ibrahim, A., Fudholi, A., Sopian, K., Othman, M.Y. and Ruslan, M.H. (2014) Efficiencies and Improvement Potential of Building Integrated Photovoltaic Thermal (BIPVT) System. Energy Conversion and Management, 77, 527-534.

[47] Agrawal, S. and Tiwari, G.N. (2011) Performance Evaluation of Hybrid Modified Micro-Channel Solar Cell Thermal Tile: An Experimental Validation. International Journal of Engineering, Science and Technology, 1, 244-245.

[48] Kleinstreuer, C. and Feng, Y. (2011) Experimental and Theoretical Studies of Nanofluid Thermal Conductivity Enhancement: A Review. Nanoscale Research Letters, 6, 1-13.

[49] Mahian, O., Kianifar, A., Kalogirou, S.A., Pop, I. and Wongwises, S. (2012) A Review of the Applications of Nanofluids in Solar Energy. International Journal of Heat and Mass Transfer, 57, 582-594.

[50] Lenert, A. and Wang, E.N. (2012) Optimization of Nanofluid Volumetric Receivers 
for Solar Thermal Energy Conversion. Solar Energy, 86, 253-265.

[51] Faizal, M., Saidur, R., Mekhilef, S. and Alim, M.A. (2013) Energy, Economic and Environmental Analysis of Metal Oxides Nanofluid for Flat-Plate Solar Collector. Energy Conversion and Management, 76, 162-168.

[52] Filho, E.P.B., Mendoza, O.S.H., Beicker, C.L.L., Menezes, A. and Wen, D. (2014) Experimental Investigation of a Silver Nanoparticle-Based Direct Absorption Solar Thermal System. Energy Conversion and Management, 84, 261-267.

[53] Karami, N. and Rahimi, M. (2014) Heat Transfer Enhancement in a PV Cell using Boehmite Nanofluid. Energy Conversion and Management, 86, 275-285.

[54] Karami, N. and Rahimi, M. (2014) Heat Transfer Enhancement in a Hybrid Microchannel-Photovoltaic Cell using Boehmite Nanofluid. International Communications in Heat and Mass Transfer, 55, 45-52.

[55] Mittal, T., Saroha, S., Bhalla, V., Khullar, V., Tyagi, H., Taylor, R.A., et al. (2013) Numerical Study of Solar Photovoltaic/Thermal (PV/T) Hybrid Collector using Nanofluids. In: ASME 2013 4th International Conference on Micro/Nanoscale Heat and Mass Transfer, ASME, Hong Kong, V001T02A007.

[56] Al-Busoul, M., Al Alawin, A., Abu Rahmeh, T., Ghrair, A., Saleh, E., Hatqawi, B., Al Abdallat, Y. and Haddad, S. (2017) Experimental Investigation on Cooling PV Modules using Nanofluids. Journal of Power Technologies.

[57] http://www.pvsyst.com/en/software/download

[58] Annual Statistical Book 2015 (2016) Section of Climatic Data. Department of Statistics, Amman.

\section{Submit or recommend next manuscript to SCIRP and we will provide best} service for you:

Accepting pre-submission inquiries through Email, Facebook, LinkedIn, Twitter, etc. A wide selection of journals (inclusive of 9 subjects, more than 200 journals)

Providing 24-hour high-quality service

User-friendly online submission system

Fair and swift peer-review system

Efficient typesetting and proofreading procedure

Display of the result of downloads and visits, as well as the number of cited articles

Maximum dissemination of your research work

Submit your manuscript at: http://papersubmission.scirp.org/

Or contact jpee@scirp.org 